\title{
Zautomatyzowane stanowisko do badań ultradźwiękowych połączeń zgrzewanych łukiem wirującym
}

\author{
Automated set-up for ultrasonic testing \\ of Magnetically Impelled Arc Butt (MIAB) welded joints
}

\section{Streszczenie}

Przedstawiono procedurę projektowania zautomatyzowanego stanowiska kontroli jakości elementów przeniesienia napędu. Scharakteryzowano analizowane obiekty i przedstawiono zadania projektowe, ze szczególnym zwróceniem uwagi na wyznaczenie warunków brzegowych. Zaproponowano koncepcje zautomatyzowanego stanowiska, porównano je i wybrano najkorzystniejsze rozwiązanie. Dla wybranej koncepcji dobrano geometrię członów struktury mechanicznej oraz przedstawiono ideę układu sterowania. Przeanalizowano technologiczność stanowiska i wykonano dokumentację rysunkową.

Słowa kluczowe: rurowe elementy cienkościenne; zgrzewanie łukiem wirującym; kontrola jakości; badania ultradźwiękowe

\begin{abstract}
The article presents the design methodology of automated set-up being used for the quality control evaluation of car drive shafts. The transmission elements were characterized, quantified and then the specific objectives of a solution were defined. The boundary conditions were also defined. The various prototypes were designed, analyzed and compared in order to choose the best one for the further development. Afterwards, the geometry of the structural members was designed for the selected concept. The idea of the control system was then proposed and developed. The drawing documentation of such set-up was prepared, with respect to the versatility and user friendliness of the system.
\end{abstract}

Keywords: tubular thin-walled components; Magnetically Impelled Arc Butt welding; quality control; ultrasonic testing

\section{Wprowadzenie \\ - projektowanie zautomatyzowanych stanowisk badawczych}

Technologia zgrzewania łukiem wirującym (Magnetically Impelled Arc Butt, MIAB) jest doskonałą odpowiedzią na aktualne zapotrzebowanie przemysłu motoryzacyjnego i przejawia szereg zalet w porównaniu z alternatywnymi technikami łączenia np. popularnym zgrzewaniem tarciowym. Wybrane korzyści z jej zastosowania to minimalizacja ilości wtrąceń i zanieczyszczeń w powstałych zgrzeinach, mniejsze zużycie energii oraz mniejsza czasochłonność procesu [1 $\div 12]$. Mimo bardzo wyraźnych zalet dostępna literatura branżowa oraz zastosowania wdrożone w rodzimym przemyśle nie są liczne. Fakt ten implikuje konieczność opracowywania nowych rozwiązań, zarówno dotyczących techniki MIAB, jak i stanowisk dedykowanych do badań połączeń wykonywanych tą metodą. Wcielenie etapu badawczego już podczas cyklu produkcyjnego, oprócz możliwości weryfikacji jakości połączenia, pozwala również na sterowanie on-line parametrami procesu zgrzewania. Uzyskując informacje na temat poprawności złącza bezpośrednio po jego wykonaniu, możliwe jest zoptymalizowanie procesu przez korektę parametrów zgrzewania. Pozwala to na redukcję czasu poświęcanego na manualne badanie jakości zgrzein oraz zmniejszenie kosztów wynikających z przestoju produkcji. Zagadnienie wysokiej jakości wyrobów, przy zachowaniu powtarzalności produkcji, jest szczególnie istotne dla przemysłu samochodowego, w którym odpowiednio wczesne wykrycie niezgodności pozwala na uniknięcie zwielokrotnienia kosztów, które mogłyby wystąpić w przypadku ujawnienia się wady dopiero podczas eksploatacji wyprodukowanego elementu.

Dr inż. Tomasz Piwowarczyk, inż. Michał Salamon, dr inż. Marcin Korzeniowski, dr inż. Paweł Sokołowski - Politechnika Wrocławska, mgr inż. Agnieszka Bicz - Przedsiębiorstwo Badawczo-Produkcyjne OPTEL Spółka z o.o.

Autor korespondencyjny/Corresponding author. tomasz.piwowarczyk@pwr.edu.pl 
Kolejnym aspektem, uzasadniającym zasadność projektowania zautomatyzowanych stanowisk badawczych, jest przewaga rozwiązań dedykowanych nad uniwersalnymi, wynikająca z możliwości większej optymalizacji procesu. Dedykowany etap badawczy może zostać dopasowany do istniejących etapów produkcji, jak również wykorzystać cechy geometryczne badanych elementów. Dzięki temu czas poświęcany na inspekcję wyrobów może być krótszy, tym samym wydajność produkcji zwiększona. W rozpatrywanym stanowisku badawczym do analizy połączeń wykonanych techniką MIAB założono zastosowanie urządzeń, które przejmą od człowieka funkcje poznawcze, intelektualne i decyzyjne. Urządzenia te spełniają następujące zadania: dokonywanie pomiarów oraz rejestracja wyników, przetwarzanie informacji (gromadzenie informacji w bazach danych, tworzenia modeli matematycznych, interpretowania wyników) oraz sterowanie procesem [13]. Rozwiązanie to jest możliwe w wyniku połączenia czterech istotnych komponentów i charakterystyk: platformy wykonawczej (urządzenia, przyrządy, systemy), procesu (ruchy, operacje i realizowane funkcje), niezależności w działaniu i źródeł energii [14].

\section{Zadanie projektowe}

Przed przystąpieniem do procesu projektowania należało ocenić potencjał analizowanego systemu do automatyzacji. Pod uwagę wzięto takie czynniki jak: wydajność procesu produkcyjnego, bezpieczeństwo, aspekty ekonomiczne, wymagania jakościowe produktów oraz potencjalne możliwości operatora [14]. Na podstawie ww. analizy oraz doświadczeń autorów, zdecydowano się na wykonanie prototypu stanowiska do oceny jakości złączy zgrzewanych łukiem wirującym z wykorzystaniem technik ultradźwiękowych. W tym celu analizowano zaproponowaną koncepcję od szkicu modelowego, przez model 3D, wizualizację, aż po wykonanie prototypu (rys. 1). Zwykle pierwszymi krokami w kierunku wykonania koncepcji są: przedstawienie analizowanego obiektu oraz opis procedury badań. Z uwagi na realizowany projekt badawczy, zarówno analizowane elementy przeniesienia napędu (rys. 2), jak i proces wytwarzania oraz oceny

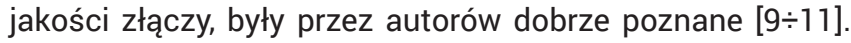
Zatem projektowanie rozpoczęto od wyznaczenia warunków brzegowych:

- czas trwania cyklu badawczego nie powinien przekroczyć 20 sekund;

- elementy do analizy dostarczane są z poprzedniego stanowiska poprzez przenośnik, ich pozycja jest zawsze znana, zawsze jednakowa dla danego rodzaju wału, jakkolwiek może różnić się w zależności od serii produkcyjnej (referencji);

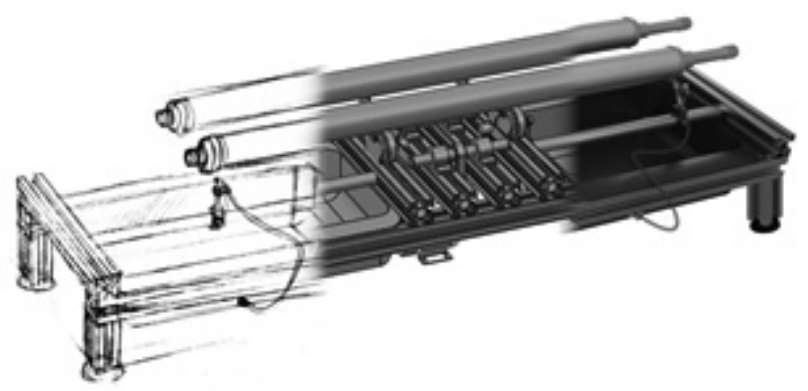

Rys. 1. Rozwój koncepcji od szkicu ideowego poprzez model 3D aż po wizualizację i prototyp

Fig. 1. The concept development; starting from concept sketch, then 3D model and finally prototype
- możliwość badania wielu rodzajów geometrii wałów, od średnic $\varnothing 36$ do $\varnothing 100 \mathrm{~mm}$ oraz długości rozstawu zgrzein od 550 do $1300 \mathrm{~mm}$;

- automatyzacja sztywna jest wystarczająca, czas przezbrajania powinien być mniejszy od czasu zmiany parametrów i konfiguracji poprzedzającego stanowiska;

- możliwe jest wykorzystanie substancji sprzęgającej na dwa sposoby: poprzez zanurzenie elementu lub zapewnienie ciągłości ośrodka przez strumień cieczy; możliwość zanurzenia wału w wodzie jest ograniczona i wymusza pionową orientację wałów lub zastosowanie uszczelnień.

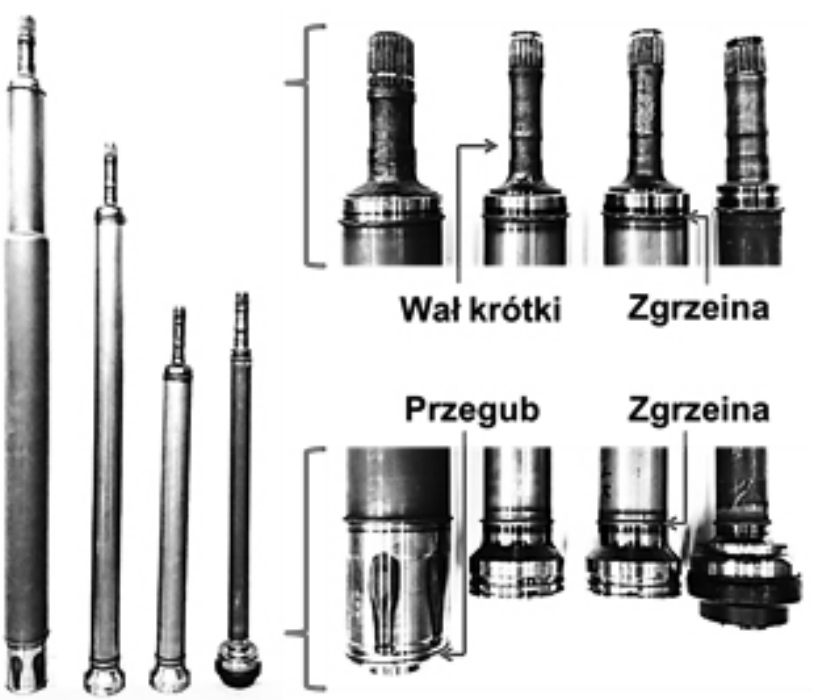

Rys. 2. Analizowane elementy przeniesienia napędu wraz ze zgrzeinami wykonanymi łukiem wirującym

Fig. 2. The analyzed drive shafts manufactured by Magnetically Impelled Arc Butt welding

\section{Proponowane koncepcje zautomatyzowanego stanowiska}

Na podstawie przedstawionych wyżej wymagań brzegowych zaproponowano 4 koncepcje stanowiska badawczego, przedstawiające różne podejścia do zagadnienia projektowego. Opis każdego rozwiązania uzupełniono wizualizacją samego stanowiska, jak i poszczególnych etapów cyklu badawczego. Uwzględniono także ocenę możliwości rozbudowy każdego projektu, uzasadnienia wyboru danych rozwiązań oraz możliwe problemy, mogące być przyczyną danego rozwiązania.

I koncepcja zakłada poziomą orientację elementów, które analizowane są jedną, bądź dwiema głowicami, przy czym ciągłość ośrodka sprzęgającego zapewniona jest za pomocą strumienia cieczy (rys. 3a).

II koncepcja korzysta z metody zanurzeniowej jako sposobu uzyskania ciągłości ośrodka pomiędzy obiektem badań a głowicą. Implikuje to konieczność zastosowania pionowej orientacji analizowanych wałów (rys. 3b).

III koncepcja zakłada użycie systemu wizyjnego lub czujników odległości, które byłyby w stanie rozpoznać rodzaj wału (rys. 3c).

IV koncepcja zakłada użycie manipulatora przemysłowego wykonującego zadanie umieszczania wału na stanowisku badawczym, a także wyjmowania go po skończonej analizie (rys. 3d).

Porównanie najważniejszych parametrów roboczych analizowanych koncepcji zestawiono w tablicy I. 
Tablica I. Porównanie najważniejszych parametrów roboczych analizowanych koncepcji Table I. The comparison of operating parameters of analyzed concepts

\begin{tabular}{|c|c|c|c|c|}
\hline \multirow[b]{2}{*}{ Numer koncepcji } & 1 & II & III & IV \\
\hline & & & & \\
\hline Gabaryty [m] & $1,44 \times 0,4 \times 0,3$ & $1,17 \times 0,8 \times 2,30$ & $1,60 \times 0,85 \times 0,82$ & $1,39 \times 0,4 \times 0,36$ \\
\hline $\begin{array}{l}\text { Konieczność } \\
\text { przezbrajania }\end{array}$ & nie & nie & tak & tak \\
\hline \multirow[b]{2}{*}{$\begin{array}{l}\text { llość oraz nazwy } \\
\text { parametrów, którymi } \\
\text { należy sterować }\end{array}$} & 2 & 4 & 3 & 2 \\
\hline & $\begin{array}{c}\text { prędkość obrotowa } \\
\text { mechanizmu } \\
\text { przemieszczającego } \\
\text { wały; } \\
\text { prędkość obrotowa rolek } \\
\text { napędowych }\end{array}$ & $\begin{array}{c}\text { przemieszczenie w osi X; } \\
\text { przemieszczenie w osi Z; } \\
\text { prędkość } \\
\text { obrotowa uchwytu } \\
\text { trójszczękowego; } \\
\text { zacisk szczęk uchwytu }\end{array}$ & $\begin{array}{l}\text { prędkość obrotowa } \\
\text { pierwszego walca } \\
\text { napędowego; } \\
\text { prędkość obrotowa } \\
\text { drugiego walca } \\
\text { napędowego; } \\
\text { przemieszczenie głowicy } \\
\text { w osi Z }\end{array}$ & $\begin{array}{l}\text { prędkość obrotowa rolek } \\
\text { napędowych; } \\
\text { położenie chwytaka } \\
\text { manipulatora } \\
\text { przemysłowego }\end{array}$ \\
\hline Konstrukcja ramy & profile aluminiowe & $\begin{array}{c}\text { profile stalowe, spawane, } \\
\text { elementy stalowe cięte } \\
\text { laserowo }\end{array}$ & profile stalowe, spawane & profile aluminiowe \\
\hline \multirow[b]{2}{*}{$\begin{array}{l}\text { Ilość i konstrukcja } \\
\text { zbiorników }\end{array}$} & 2 & 2 & 1 & 2 \\
\hline & $\begin{array}{l}\text { jedno-elementowe; } \\
\text { zbiorniki z PE lub PP }\end{array}$ & $\begin{array}{c}\text { zbiornik } \\
\text { z przezroczystych płyt } \\
\text { z PMMA; } \\
\text { rezerwuar z PE lub PP }\end{array}$ & $\begin{array}{l}\text { zbiornik z tworzywa } \\
\text { sztucznego }\end{array}$ & $\begin{array}{c}\text { zbiornik } \\
\text { z przeźroczystych płyt } \\
\text { z PMMA; } \\
\text { rezerwuar z PE lub PP }\end{array}$ \\
\hline Orientacja wałów & pozioma & pionowa & pozioma & pozioma \\
\hline $\begin{array}{l}\text { Sposób uzyskania } \\
\text { ciągłości ośrodka }\end{array}$ & strumieniem cieczy & zanurzeniowy & strumieniem cieczy & strumieniem cieczy \\
\hline Potencjał rozbudowy & fatwa & problematyczna & nieopłacalna & latwa \\
\hline Sposób przezbrojenia & $\begin{array}{l}\text { 1) zatrzymanie } \\
\text { przepływu cieczy; } \\
\text { 2) spozycjonowanie } \\
\text { głowic; } \\
\text { 3) wznowienie przepływu }\end{array}$ & $\begin{array}{l}\text { 1) opróżnienie zbiornik; } \\
\text { 2) spozycjonowanie } \\
\text { głowic; } \\
\text { 3) napełnienie zbiornika }\end{array}$ & $\begin{array}{l}\text { brak konieczności } \\
\text { przezbrajania }\end{array}$ & $\begin{array}{l}\text { w razie konieczności } \\
\text { 1) zatrzymanie } \\
\text { przepływu cieczy; } \\
\text { 2) spozycjonowanie } \\
\text { głowic; } \\
\text { 3) wznowienie przepływu }\end{array}$ \\
\hline $\begin{array}{c}\text { Minimalny kąt obrotu } \\
\text { wału }\end{array}$ & $\begin{array}{c}\text { ok. } 360^{\circ} \text {, ok. } 180^{\circ} \\
\text { w przypadku dodania } \\
\text { głowicy po przeciwnej } \\
\text { stronie }\end{array}$ & $\begin{array}{c}\text { ok. } 360^{\circ} \text {, ok. } 180^{\circ} \\
\text { w przypadku dodania } \\
\text { głowicy po przeciwnej } \\
\text { stronie }\end{array}$ & więcej niż $360^{\circ}$ & ok. $360^{\circ}$ \\
\hline $\begin{array}{l}\text { Sposób podawania } \\
\text { elementów }\end{array}$ & $\begin{array}{l}\text { mechanizm oparty } \\
\text { na czworoboku } \\
\text { przegubowym }\end{array}$ & $\begin{array}{c}\text { chwytak poruszający się } \\
\text { w osi X i Z }\end{array}$ & $\begin{array}{l}\text { grawitacyjnie, } \\
\text { bezpośrednio } \\
\text { z podajnika }\end{array}$ & $\begin{array}{l}\text { manipulator } \\
\text { przemysłowy }\end{array}$ \\
\hline $\begin{array}{c}\text { Sposób zapewnienia } \\
\text { obrotu wału }\end{array}$ & napęd rolkowy & uchwyt trójszczękowy & napęd bębnów & napęd rolkowy \\
\hline
\end{tabular}




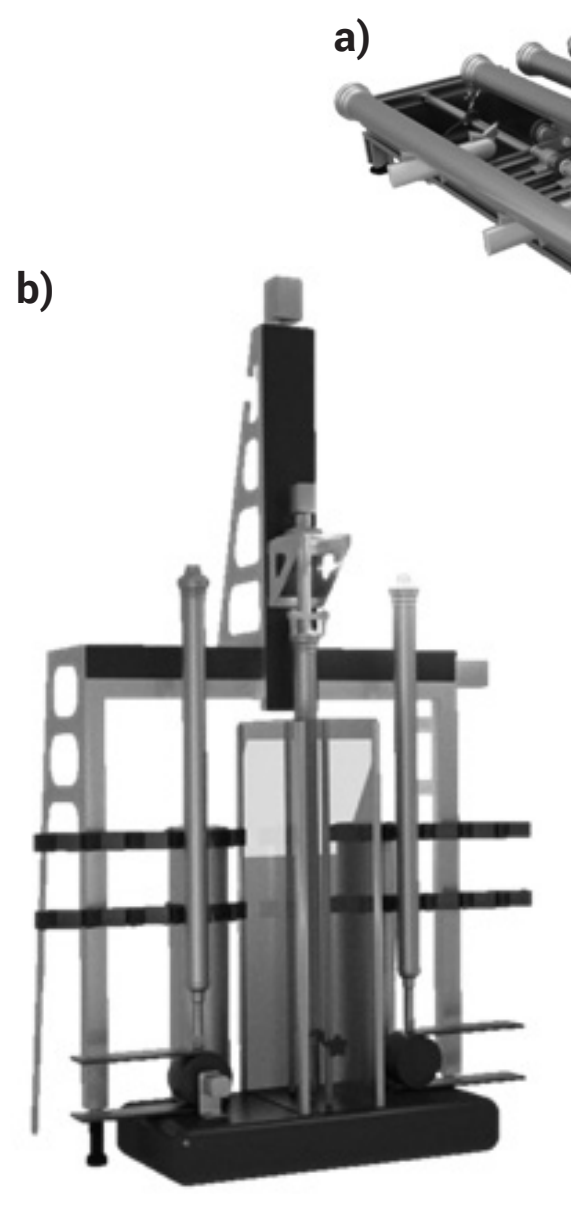

a)

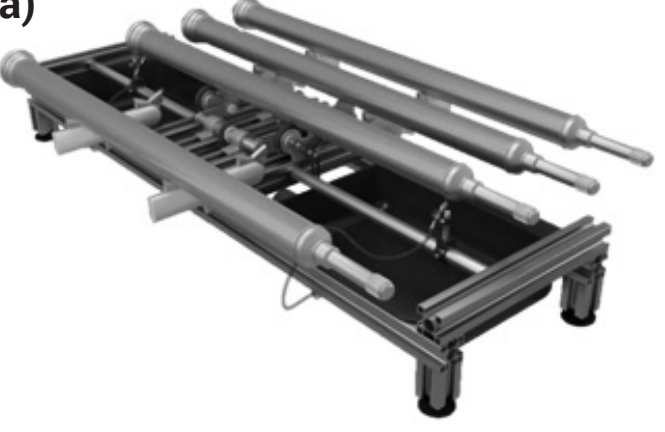

c)
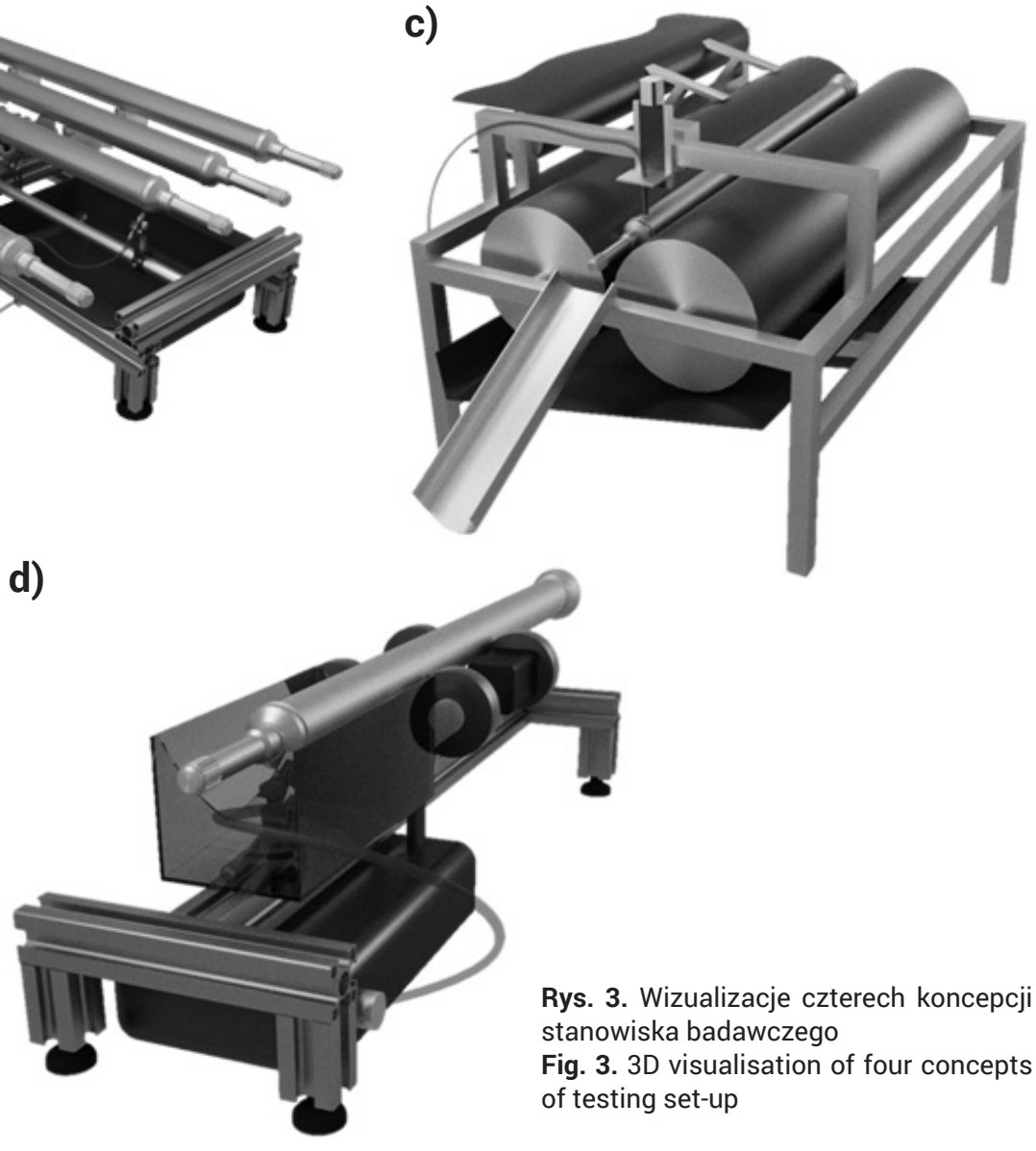

Rys. 3. Wizualizacje czterech koncepcji stanowiska badawczego

Fig. 3. 3D visualisation of four concepts of testing set-up
W celu wytypowania najkorzystniejszego rozwiązania spośród proponowanych koncepcji przyjęte zostały kryteria wyboru obejmujące zarówno wymagania odnośnie wytworzenia stanowiska, jak i jego eksploatacji:

- czas pomiaru elementu - w głównej mierze zależy od czasu, który poświęcany jest na obrót elementu wokół własnej osi, jest zależny od typu (średnicy) aktualnie badanego wału. Jest to okres pomiędzy dotarciem elementu do stanowiska badawczego a opuszczeniem go;

- prostota konstrukcji - określa stopień skomplikowania wykonania, rodzaj użytych elementów możliwość szybkiej wymiany dowolnego podzespołu w razie awarii;

- koszt budowy - koszty wynikające z zakupu podzespołów użytych do wykonania stanowiska, jego montażu i przygotowania do pracy;

- zajmowana powierzchnia - rozumiana jako obszar hali produkcyjnej, który musi zostać wydzielony dla projektowanego etapu produkcji;

- czas przezbrojenia - czas potrzebny na zmianę konfigracji stanowiska i przystosowanie go do nowego typu elementów;

- możliwość rozbudowy - wyraża sposobność dostosowania układu do wymagań stawianych przez gabaryty i geometrię elementów, które mogą być produkowane w przyszłości.

W pierwszym kroku wyznaczono wagę danego kryterium, czyli oceniono jak ważny jest poszczególny warunek z punktu widzenia rozpatrywanego zadania projektowego i stawianych mu wymagań brzegowych. Następnie porównano poszczególne rozwiązania konstrukcyjne ze względu na przyjęte kryteria metodą „każdy z każdym”. Na tej podstawie otrzymano sumaryczną liczbę punktów przypisanych do danej koncepcji, które po uwzględnieniu współczynników istotności pozwoliło na wybór najlepszego rozwiązania (tabl. 2). Z przeprowadzonych rozważań wynika, że najbardziej odpowiednim rozwiązaniem dla wyznaczonych kryteriów jest pierwsza koncepcja stanowiska badawczego, która to została w następnych etapach rozwinięta.
Tablica II. Podsumowanie ocen punktowych stanowisk wraz z uwzględnieniem wag każdego kryterium

Table II. The summary of the best concept selection process and weighting of each criteria

\begin{tabular}{|c|c|c|c|c|}
\hline & I & II & III & IV \\
\hline Czas pomiaru elementu & 0,13 & 0 & 0,04 & 0,04 \\
\hline Prostota konstrukcji & 0,09 & 0,04 & 0 & 0,09 \\
\hline Koszt budowy & 0,04 & 0,02 & 0 & 0,04 \\
\hline Zajmowana powierzchnia & 0,07 & 0,02 & 0 & 0,02 \\
\hline Czas przezbrojenia & 0,01 & 0,00 & 0,03 & 0,01 \\
\hline Możliwość rozbudowy & 0,04 & 0,02 & 0 & 0,04 \\
\hline SUMA & 0,39 & 0,11 & 0,08 & 0,26 \\
\hline
\end{tabular}

\section{Projekt technologiczny i konstrukcyjny wybranej koncepcji}

Wybrana koncepcja zakłada obrót wału, konieczny do inspekcji całej długości połączenia, dokonywany za pomocą rolek napędzanych silnikiem elektrycznym. Napęd przenoszony jest za pomocą pasów zębatych, a sama jednostka napędowa umiejscowiona jest pod konstrukcją. Uzasadnieniem wyboru tego rozwiązania jest chęć ograniczenia drgań wprowadzanych do układu badawczego. Proponowanymi elementami do budowy konstrukcji ramy są profile aluminiowe łączone głównie za pomocą kątowników. Stanowisko zautomatyzowane jest w sposób wymagający każdorazowego przezbrojenia przy zmianie 
a)

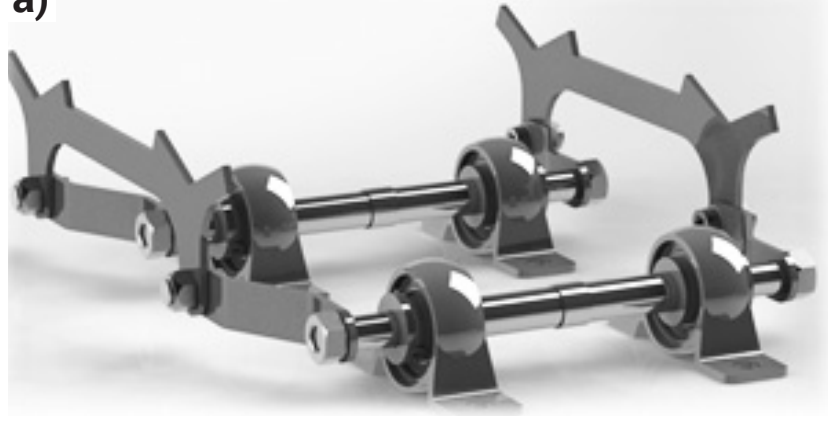

b)

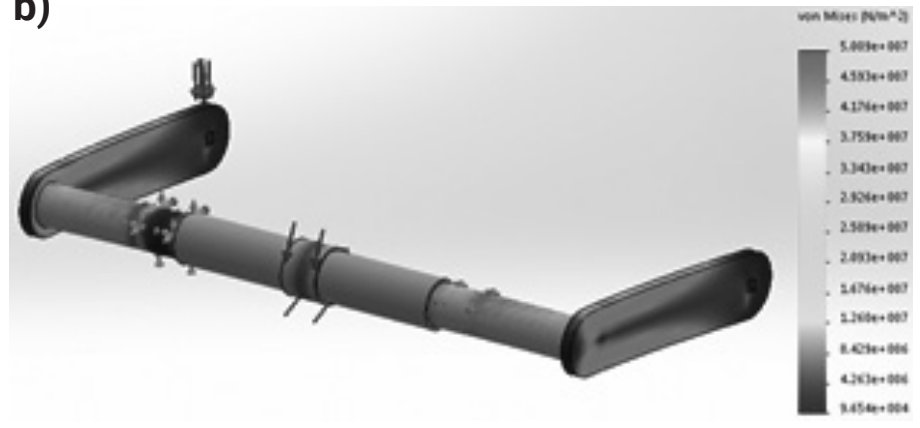

Rys. 4. a) Wizualizacja mechanizmu transportującego elementy, b) analiza wytrzymałościowa ukształtowanego wału

Fig. 4. a) $3 \mathrm{D}$ visualisation of mechanism that enables the transport of drive shafts, b) FEM strength analysis of a critical structural member

typu produkowanego elementu. Elementy podawane są w sposób automatyczny, a ich pozycja początkowa jest ustalona przez przenośnik łańcuchowy, którego układ mechaniczny nie jest powiązany z konstrukcją stanowiska. Podawanie elementów jest realizowane dzięki mechanizmowi opartemu na czworoboku przegubowym z uchwytami pryzmatycznymi pokrytymi gumą, które zapewniają pewny chwyt transportowanego elementu cylindrycznego. Silnik elektryczny napędzający powyższy mechanizm również posadowiony jest poniżej ramy, a moment obrotowy przenoszony jest za pomocą pasa na wał, wsparty na dwóch łożyskach, których obudowa przytwierdzona jest do ramy. Stosowanie substancji sprzęgającej w postaci strumienia cieczy wymusza na konstrukcji zastosowanie zbiorników pozwalających na zamknięty obieg wody. Do tego niezbędna jest pompa cieczy, która nie wymaga sterowania i może pracować w trybie ciągłym. Dostosowanie stanowiska do wymagań narzucanych przez geometrię kolejnej serii wałów odbywa się poprzez zmianę położenia stoperów, ustalanych dla każdego rodzaju referencji. Pozycja oraz kąt nachylenia ustawiany jest za pomocą pokręteł dających możliwość zablokowania ruchu w każdym kierunku. Proponowana konstrukcja umożliwia zastosowanie kolejnej pary głowic, obróconych względem osi wału o $180^{\circ}$, co spowoduje, że wystarczające będzie obrócenie wału o połowę pierwotnej wartości kątowej, a tym samym pozwoli na skrócenie czasu inspekcji o połowę. Zastosowanie profili aluminiowych połączonych śrubowo daje konstrukcji możliwość dostosowania się do przyszłych specyfikacji badanych produktów, opcję rozbudowy oraz sposobność do manipulacji rozstawem rolek napędowych.

Dla wybranej koncepcji zaprojektowano poszczególne elementy konstrukcji stanowiska badawczego, z podziałem na określone podzespoły tworzące złożenie, wydzielone na podstawie pełnionej funkcji:

- mechanizm transportujący wały, oparty na czworoboku przegubowym,

- mechanizm zapewniający obrót wału wokół własnej osi napęd rolkowy,

- układ zapewniający obieg powrotny cieczy sprzęgającej,

- konstrukcja ramy,

- układ sterujący.

Mechanizm oparty na czworoboku przegubowym w projektowanym stanowisku badawczym pełni funkcję przenoszenia elementów z przenośnika łańcuchowego na rolki napędowe oraz równocześnie transportuje zbadany już wał na kolejny przenośnik łańcuchowy (rys. 4). $\mathrm{Na}$ dwa identyczne, równoległe względem siebie wały zostaje przyłożony moment obrotowy, wprawiający w ruch pozostałe człony mechanizmu. W pierwszym etapie ruchu, człon na którym spoczywają przenoszone elementy przemieszcza się po łuku zapewniając przy tym bezkolizyjne przemieszczenie elementów. Po umieszczeniu ich na docelowym miejscu mechanizm wraca do położenia początkowego, tym samym wykonując pełen obrót, i pozostaje nieruchomy do czasu konieczności przetransportowania kolejnych części. Dla założonego projektu przeprowadzono analizę wytrzymałościową i wymagane obliczenia.

Mechanizm rolkowy ma za zadanie przeniesienie momentu obrotowego wytwarzanego przez silnik elektryczny i wykorzystanie go do obracania badanych elementów wokół własnej osi. Elementy elektromechaniczne stanowiska tj. silnik krokowy, dzięki któremu możliwy jest ruch obrotowy wału, oraz pompa doprowadzająca ciecz sprzęgającą w obszar zgrzeiny, sterowane są przez komputer będący integralną częścią systemu. Prędkość obrotowa silnika (możliwa do regulacji z poziomu interfejsu administratora systemu) jest ściśle związana z momentem wyzwalania impulsu ultradźwiękowego, generowanego przez kartę ultradźwiękową OpBox. Synchronizacja generatora fal ultradźwiękowych z silnikiem krokowym jest możliwa dzięki wykorzystaniu enkodera, w który dodatkowo wyposażono silnik. Tok analizy mechanizmu był następujący: wyznaczono siły działające na rolki i dobrano komponenty, wyznaczono wymagany moment obrotowy i dobrano silnik.

Szczególnie ważnym wymogiem stawianym projektowanemu stanowisku jest uniwersalność, stąd też dokonano wyboru konstrukcji ramy opartej na profilach aluminiowych. Wszechstronność tego typu rozwiązania polega na modułowości podzespołów oferowanych przez producentów. Odpowiednio dobrane długości elementów mogą być łączone na wiele sposobów, bez konieczności wiercenia otworów, za pomocą połączeń śrubowych. Umożliwia to wprowadzenie korekty, gdyby w przyszłości wystąpiła konieczność modyfikacji stanowiska w celu dostosowania go pod wymogi nowej partii produktów.

Dane charakterystyczne zastosowanych pomp wodnych są determinowane przez parametry procesu badań ultradźwiękowych oraz budowę głowicy kierunkującej strumień cieczy. W celu sprawdzenia zaprojektowanej pompy została przeprowadzona symulacja cyrkulacji cieczy. W tym celu wymuszono przepływ o stałej prędkości, zbliżonej szacunkowo do wartości pozwalającej na prawidłowy przebieg procesu badawczego (rys. 5).

Projektując układ sterowania wzięto pod uwagę fakt, że system sterowania napędami i układ badawczy mogą działać niezależnie, zatem do obu zadań zastosowano komputer. Wiązka fali ultradźwiękowej jest generowana w określonych przez enkoder punktach. Po wejściu generowanej fali $w$ badany element, propaguje ona podpowierzchniowo do zgrzeiny i przechodzi dalej (zgrzeina poprawna) lub odbija się od nieciągłości wewnątrz połączenia. 


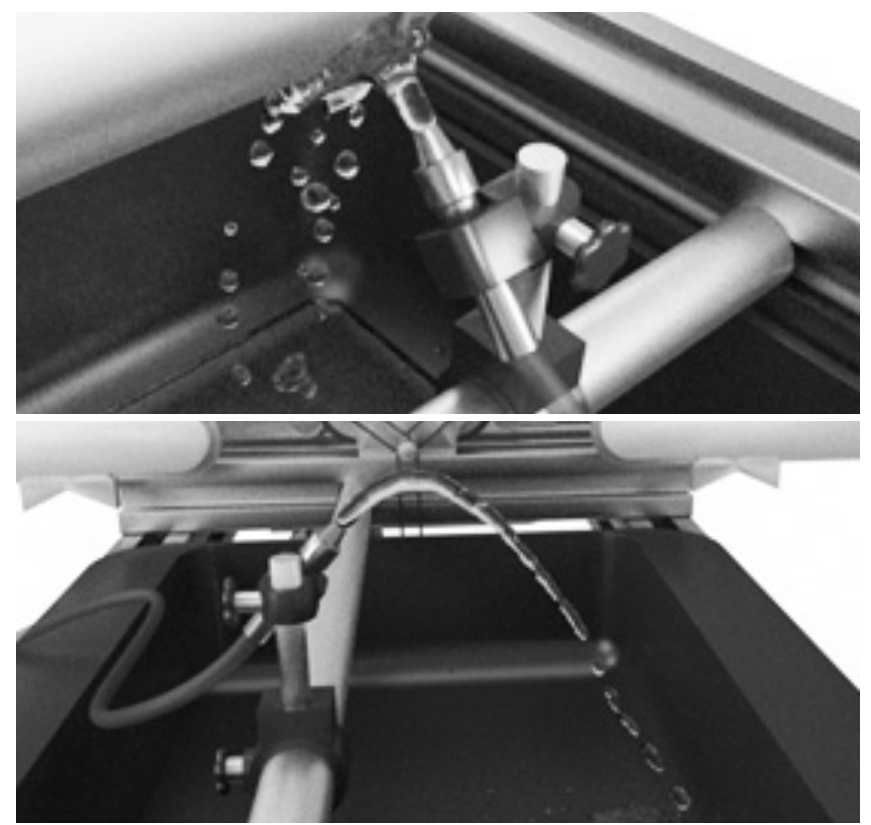

Rys. 5. Wizualizacja przepływu cieczy podczas badania elementu Fig. 5. The simulation of a coupling liquid flow during ultrasonic testing

\section{Prototyp stanowiska badawczego}

Na podstawie założeń wyznaczonych w poszczególnych etapach projektowych zbudowano prototyp urządzenia (rys. 6a), którego główne cechy charakterystyczne to:

- możliwość wykonywania ultradźwiękowych skanów typu B badanych połączeń na całym obwodzie elementu o założonym zakresie średnic i długości, ze zdefiniowaną przez użytkownika rozdzielczością,

- możliwość tworzenia oraz zapisu konfiguracji systemu dla wykonywania skanów poszczególnych typów elementów zgrzewanych,

- możliwość kontroli oraz konfiguracji sygnałów ultradźwiękowych uzyskiwanych w czasie skanu,

- możliwość zapisu wykonanych skanów wraz z konfiguracją systemu on-line.

Rozpoczęcie pomiaru możliwe jest po prawidłowym ułożeniu wału przez mechanizm transportujący na rolkach, połączonych z napędzającym silnikiem za pomocą przekładni pasowej. Pomiar ciągłości zgrzeiny wyzwalany jest przyciskiem „Start" umieszczonym na zewnętrznej części szafy sterującej lub poprzez aktywowanie przycisku "Start Scan” w oknie głównym aplikacji sterującej. W celu zapewnienia dokładnego sprzężenia akustycznego pomiędzy przetwornikiem ultradźwiękowym, a powierzchnią rury, ruch obrotowy wału poprzedzony jest ok. 4-sekundowym załączeniem pompy, doprowadzającej ciecz sprzęgającą w obszar badania. Jest to najczęściej wodny roztwór z inhibitorem korozji, mający własności hydrofobowe, dzięki czemu po wykonaniu badania wał nie wymaga suszenia (rys. 6b).

Zintegrowane z układem mechanicznym oprogramowanie, oprócz możliwości sterowania ruchem umożliwia kompletną akwizycję i rejestrację sygnałów ultradźwiękowych. Jego elastyczność daje użytkownikowi pełną kontrolę nad takimi parametrami jak:

- czułość pomiarowa i rozdzielczość,

- zapis i odczyt konfiguracji systemu dla wykonywania badań wybranych przez operatora półosi,

- podgląd w czasie rzeczywistym oraz konfigurację sygnałów ultradźwiękowych uzyskiwanych w czasie wykonywania pomiaru,

- zapis i odczyt wykonanych pomiarów wraz z równoczesną konfiguracją systemu w trakcie wczytywanego wyniku pomiaru.

a)
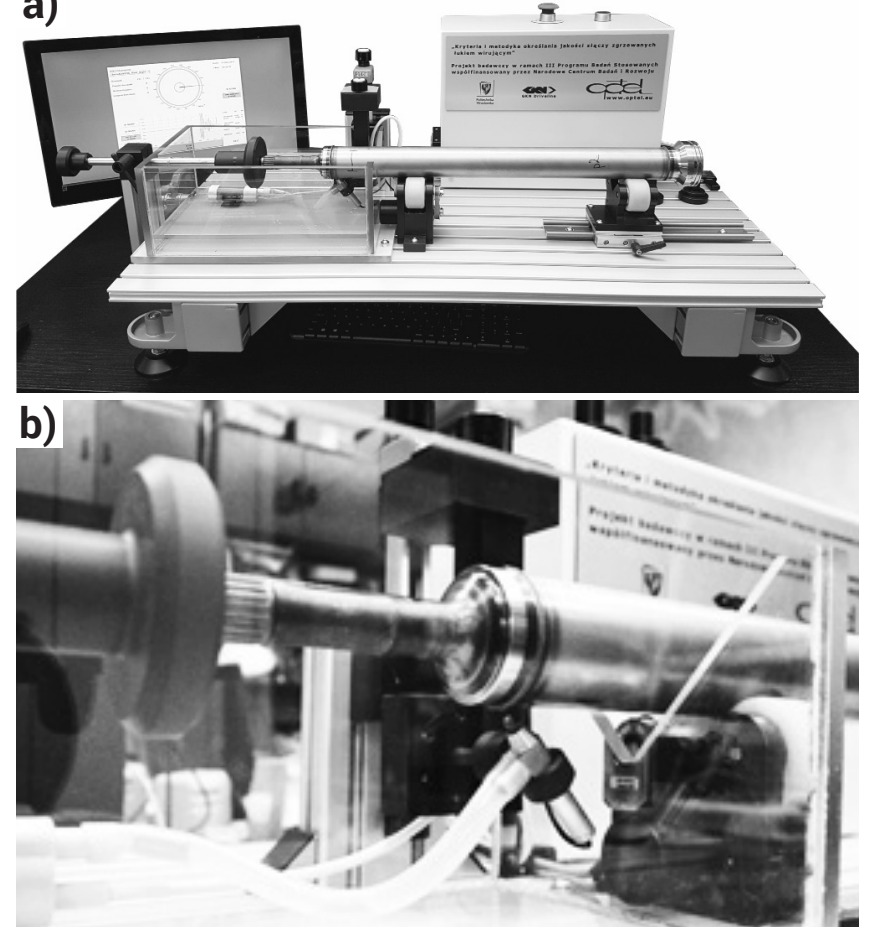

Rys. 6. Prototyp stanowiska badawczego

Fig. 6. Prototype of the testing setup

\section{Podsumowanie}

Na podstawie zrealizowanych etapów procedury projektowej opracowano stanowisko badawcze i wykonano jego prototyp. Początkowo sprecyzowano warunki brzegowe i na ich podstawie powstały 4 koncepcje stanowiska. Dzięki wytypowaniu i porównaniu najważniejszych cech i parametrów wszystkich wstępnych projektów dokonano wyboru koncepcji najkorzystniejszej pod względem założonych kryteriów. Następnym krokiem było dobranie geometrii członów struktury mechanicznej na podstawie analizy wytrzymałościowej i dobór elementów układu mechatronicznego. Zaprezentowano także ideę układu sterowania oraz stworzono rysunki techniczne części tworzących konstrukcję stanowiska. Realizację doboru poszczególnych elementów złożenia w znacznym stopniu ułatwiły programy do komputerowego wspomagania projektowania, dzięki którym możliwe było przeprowadzenie symulacji pracy w zadanych warunkach. Na podstawie przeprowadzonych prac projektowych wykonano prototyp urządzenia i przeprowadzono testy na rzeczywistych obiektach.

Artykuł powstał w ramach projektu pt. "Kryteria i metodyka określania jakości złączy zgrzewanych łukiem wirującym” współfinansowanym przez Narodowe Centrum Badań i Rozwoju w ramach III Programu Badań Stosowanych. 


\section{Literatura}

[1] S. Arungalai Vendan, S. Manoharan, G. Buvanashekaran, C. Nagamani: Development of a MIAB welding module and experimental analysis of rotational behavior of arc-simulation of electromagnetic force distribution during MIAB welding of steel pipes using finite element analysis, The International Journal of Advanced Manufacturing Technology, 2009, nr 43.

[2] D. H. Phillips: Magnetically Impelled Arc Butt (MIAB) welding of chromium-plated steel tubular components utilizing arc voltage monitoring techniques, Rozprawa doktorska, The Ohio State University, 2008.

[3] I. Kubiszyn: Zbadanie warunków zgrzewania łukiem wirującym, Praca badawcza Instytutu Spawalnictwa, nr Ba-37, Gliwice 1980.

[4] P. Lassociński: Podstawy teoretyczne zgrzewania łukiem wirującym, Przegląd Spawalnictwa, 1992, nr 1.

[5] P. Lassociński: Urządzenia do zgrzewania łukiem wirującym, Przegląd Spawalnictwa, 1993, nr I.

[6] M. Florkowski, M. Korzeniowski, T. Piwowarczyk: Zastosowanie zgrzewania łukiem wirującym do łączenia elementów o przekroju rurowym, Sympozjum Katedr i Zakładów Spawalnictwa, Nowoczesne zastosowania technologii spawalniczych, Politechnika Śląska, Istebna 2016.

[7] S. Arungalai Vendan, S. Manoharan, G. Buvanashekaran, C. Nagamani: Investigation of weld parameters in MIAB welding process by developing a module - Validation using Finite Element Analysis, International Journal of Manufacturing Engineering, 2008, nr 4.
[8] J. W. Kim, D. H. Choi: A study on the numerical analysis of magnetic flux density by a solenoid for magnetically impelled arc butt welding, Proceedings of the Institution of Mechanical Engineers, Part B: Journal of Engineering Manufacture, 2003, nr 10.

[9] T. Piwowarczyk, A. Małachowska, P. Sokołowski: Tendencje rozwojowe zgrzewania łukiem wirującym w aspekcie zastosowań w przemyśle motoryzacyjnym, Przegląd Spawalnictwa, 2013, nr 6.

[10] T. Piwowarczyk, M. Korzeniowski, A. Ambroziak, R. Rutka, S. Krzywański, M. Karolewski: Ocena jakości komponentów zgrzewanych łukiem wirującym, Przegląd spawalnictwa, 2016, nr 6.

[11] T. Piwowarczyk, A. Małachowska, P. Sokołowski: Zgrzewanie łukiem wirującym, w Ferenc K. Technika spawalnicza w praktyce, Poradnik inżyniera, konstruktora i technologa, 2014.

[12] Merkblatt DVS 2934, Preßschweißen mit magnetisch bewegtem Lichtbogen (MBP-Schweißen), 2001.

[13] J. Barczyk: Automatyzacja procesów dyskretnych, Warszawa: Oficyna Wydawnicza Politechniki Warszawskiej, 2003.

[14] G. Kost, P. Łebkowski, Ł. N. Węsierski: Automatyzacja i robotyzacja procesów produkcyjnych, Warszawa, Polskie Wydawnictwo Ekonomiczne, 2013. 